\title{
Sinkronisasi Pengaturan Honorarium Jasa Notaris antara UUJN dengan Kode Etik Notaris
}

\author{
Vennie Yunita Laytno1, I Ketut Rai Setiabudhi ${ }^{2}$ \\ 1Program Studi Magister (S2) Kenotariatan Fakultas Hukum Universitas Udayana, Bali- \\ Indonesia, E-mail: yunitavennie@gmail.com \\ ${ }^{2}$ Fakultas Hukum Universitas Udayana, Bali-Indonesia, \\ E-mail: raisetiabudhi_fhunud@yahoo.com
}

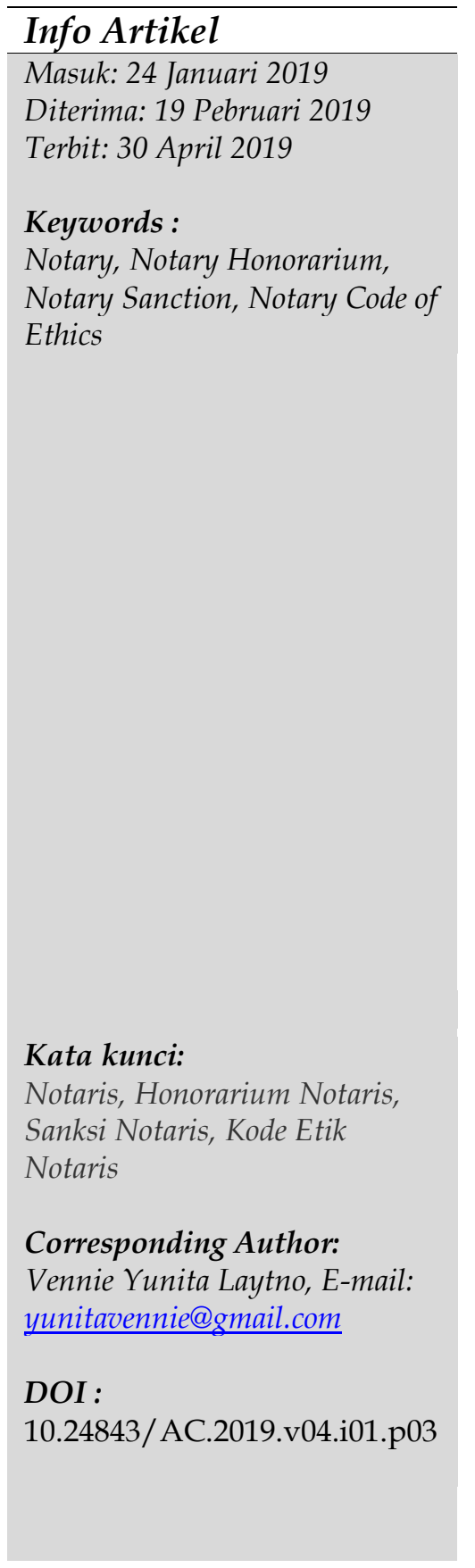

\begin{abstract}
Research on synchronization of honorarium arrangements for notary services based on the synchrony of regulations in Article 36 paragraph (2) of UUJN which regulates the highest honorarium determined by notaries and Article 4 number 10 Notary Ethics Code regulates the lowest limit of honorarium set by notary associations. Based on this, the formulation of the problem: (1) What are the arrangements for the honorarium of notary services? (2) Is the sanction for a notary who does not comply with the Notary Code of Ethics regarding the rules regarding the honorarium of notary services? The purpose of this paper for know the arrangement of honorarium for notary services regulated in UUJN and Notary Code of Ethics; and to review and analyze sanctions for notaries who do not follow the rules of the Notary Ethics Code regarding regulations regarding the honorarium of notary services. The research is applied to review these legal rules, namely normative legal research carried out by applying the Statute Approach and Conceptual Approach. Legal materials are primary legal materials, secondary legal materials, and tertiary legal materials. The regulation about honorarium that applies to a notary is Article 36 paragraph (3) of the UUJN which is concerning the highest limit of the honorarium that may be accepted by a notary; and Notaries who do not comply with the regulations stated in Article 4 number 10 of the Notary Code of Ethics they should not be punished because based on an agreement between the notary and the viewers.
\end{abstract}

\begin{tabular}{l}
\hline Abstrak \\
\hline Penelitian tentang sinkronisasi pengaturan honorarium jasa \\
notaris berdasarkan ketidak sinkronan peraturan pada Pasal 36 \\
ayat (2) UUJN yang mengatur tentang batas tertinggi \\
honorarium yang ditentukan oleh notaris dan Pasal 4 angka 10 \\
Kode Etik Notaris mengatur tentang batas terendah honorarium \\
yang telah ditetapkan oleh perkumpulan notaris. Berdasarkan \\
hal tersebut maka dirumuskan rumusan permasalahan, yaitu: \\
(1) Bagaimanakah pengaturan tentang honorarium jasa notaris? \\
(2) Apakah sanksi bagi notaris yang tidak mematuhi aturan \\
Kode Etik Notaris terkait aturan mengenai honorarium jasa \\
notaris? Tujuan dari penulisan ini yaitu untuk mengetahui dan \\
memahami pengaturan honorarium jasa notaris yang diatur \\
dalam UUJN dan Kode Etik Notaris; serta untuk mengkaji dan \\
menganalisis sanksi bagi notaris yang tidak mengikuti aturan
\end{tabular}




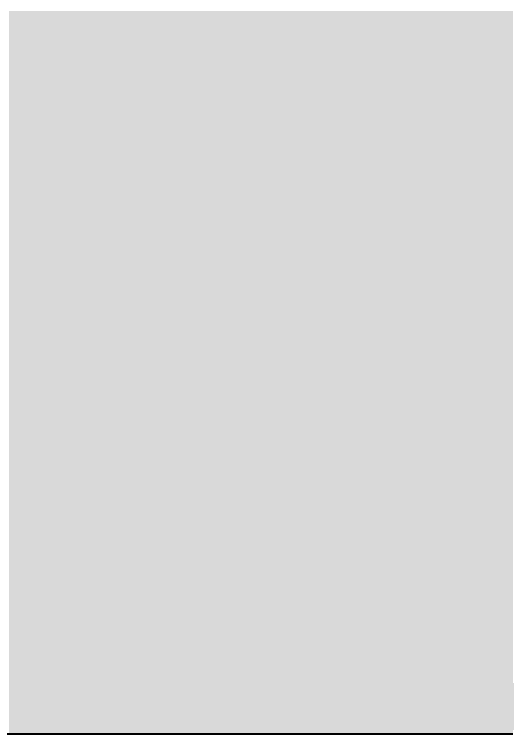

Kode Etik Notaris terkait peraturan mengenai honorarium jasa notaris. Penelitian dalam bidang hukum yang diterapkan untuk mengkaji aturan hukum ini yakni penelitian hukum yang bersifat normatif yang dilakukan dengan cara melakukan pendekatan perundang-undangan (The Statute Approach) serta pendekatan konseptual (Conceptual Approach). Bahan hukum dari penelitian ini adalah bahan hukum primer, bahan hukum sekunder, dan bahan hukum tersier. Pengaturan tentang honorarium yang berlaku bagi notaris adalah Pasal 36 ayat (3) UUJN yaitu mengenai batas tertinggi dari penetapan honorarium yang boleh diterima oleh notaris; dan Notaris yang tidak memenuhi peraturan yang tertera didalam Pasal 4 angka 10 Kode Etik Notaris terkait batas terendah dari honorarium yang telah ditetapkan oleh perkumpulan sepatutnya tidak dikenakan sanksi karena berdasarkan kesepakatan antara notaris dan para penghadap.

\section{Pendahuluan}

Notaris adalah seseorang yang memiliki tugas untuk membuat akta, dalam hal pembuatan suatu akta, notaris harus paham betul tentang apa yang diinginkan para pihak dan kemudian menuangkannya dalam sebuah akta yang tata cara pembuatannya telah ditentukan. Menurut Pasal 1 angka 1 Undang-Undang Nomor 2 Tahun 2014 tentang Perubahan Atas Nomor Undang-Undang Nomor 30 Tahun 2004 tentang Jabatan Notaris (selanjutnya disebut UUJNP) dinyatakan bahwa Notaris adalah seorang yang memiliki jabatan umum yang memiliki kewenangan untuk membuat akta autentik dan juga mempunyai kewenangan selain pembuatan akta autentik sesuai yang diatur dalam undang - undang ini serta undang - undang lainnya. Pengertian notaris juga terdapat dalam Kode Etik Notaris Pasal 1 angka 4 yaitu Notaris merupakan orang perorangan yang mengemban tugas dan melaksanakan tugasnya sebagai pejabat umum, sesuai dengan yang diatur dalam UUJN.

Kode Etik Notaris memiliki pengertian yaitu seluruh aturan moral bagi notaris untuk mejalankan tugas dan jabatannya yang berisi larangan dan kewajiban serta pengecualian bagi notaris dalam melaksanakan jabatannya. Kode etik notaris dibentuk oleh sebuah kumpulan dari notaris yaitu Ikatan Notaris Indonesia yang berisi tentang seluruh aturan mengenai moral yang telah ditentukan oleh Perkumpulan yang bergabung dalam Ikatan Notaris Indonesia (selanjutnya disebut dengan Perkumpulan) berdasarkan keputusan Kongres Perkumpulan dan aturan undang - undang yang menetapkan tata cara kerja notaris yang berlaku bagi notaris anggota Ikatan Notaris Indonesia serta setiap orang yang bertugas dan menjabat sebagai notaris, selain itu juga termasuk juga notaris pengganti yang sedang menjalankan tugas dan pekerjaannya serta pejabat yang hanya sementara bertugas sebagai notaris.

Undang - undang dan masyarakat yang menggunakan jasa notaris mempercayakan terjaminnya pelaksanaan tugas dan jabatan notaris dengan jujur dan terpercaya, oleh karena itu adanya pengaturan secara umum dalam hal pengawasan kinerja notaris sangatlah diperlukan. Dengan adanya Kode Etik Notaris sebagai sarana kontrol sosial 
maka kepercayaan dan kepentingan masyarakat menjadi terjamin dan diharapkan meminimalisir terjadinya masalah di kemudian hari, ${ }^{1}$

Notaris dalam menjalankan pekerjaannya harus bertanggungjawab atas apa yang telah dibuatnya. Tanggung jawab seorang notaris terdiri dari 3 (tiga) unsur pokok yang harus dipenuhi, yaitu suatu akta akan dikatakan autentik apabila telah memenuhi syarat yang ditentukan didalam aturan undang-undang. Unsur kedua, suatu akta autentik wajib disusun sedemikian rupa oleh notaris dan juga dihadapan notaris selaku pejabat umum. Kemudian unsur yang ketiga, akta autentik wajib disusun dan disahkan oleh notaris selaku pejabat umum yang memiliki kewenangan untuk menyusun dan mengesahkan akta tersebut serta harus pada tempat di mana akta tersebut disusun dan disahkan. ${ }^{2}$ Notaris dalam menjalankan kewajiban diharapkan agar menjalankan pekerjaannya secara professional, dengan semangat dan ketelitian pada kemampuan berupa kecerdasan serta dapat berpendapat secara rasional dan kritis, serta menjunjung tinggi nilai - nilai moral. ${ }^{3}$

Notaris selaku pejabat pembuat akta otentik harus memiliki sebuah keahlian khusus dan pengetahuan yang luas yang tidak dimiliki pejabat/profesi lainnya. Tugas seorang notaris yaitu memformulasikan secara tertulis dan otentik perjanjian - perjanjian para penghadap yang meminta jasa notaris. Notaris harus mengetahui batas - batas kewenangannya dalam menjalankan tugas dan kewenangannya, serta menaati semua aturan hukum yang telah ditentukan bagi notaris sebagai pejabat umum. Semua orang dalam melakukan pekerjaan memiliki tujuan untuk mencari uang, begitu pula dengan notaris sendiri yang melakukan pekerjaan untuk mencari uang, tetapi bukan hal itu saja, notaris harus memiliki sifat sosial yang tidak harus melihat pada uang saja. ${ }^{4}$ Pengangkatan notaris dilakukan oleh pemerintah, tetapi pemerintah mengangkat seorang notaris tidak hanya ditujukan untuk kepentingan dan kwenangan notaris yang diangkat saja disamping itu demi kepentingan seluruh anggota masyarakat. Jasa pembuatan akta serta perjanjian - perjanjian yang dibuat oleh notaris berkaitan erat dengan kepercayaan yang diberikan para pihak kepada notaris tersebut. Hal ini sama dengan negaralah yang sebenarnya memberikan kepercayaan kepada notaris untuk menangani persoalan pembuatan akta yang diperlukan masyarakat. ${ }^{5}$

Notaris dalam menjalankan tugasnya bisa melakukan berbagai pelanggaran. Notaris tersebut bisa melakukan pelanggaran terkait UUJN, Kode Etik Notaris, ataupun peraturan perundang - undangan lainnya. Pelanggaran-pelanggaran yang rentan dilakukan notaris seharusnya dihindari oleh notaris sendiri, oleh karena itu perlu dilakukan tindakan pencegahan dengan cara mengkaji lebih mendalam peraturan yang mengatur notaris khususnya UUJN dan Kode Etik Notaris agar semua kegiatan

${ }^{1}$ Prayojana, D. A., Murni, R. R., \& Dharmawan, N. K. S. (2018). Pelaksanaan Penyelesaian Pelanggaran Kode Etik Notaris Tentang Pemasangan Papan Nama Notaris Di Kota Denpasar. Acta Comitas, h. 214.

2 Soerodjo, I, (2003), Kepastian Hukum Hak Atas Tanah di Indonesia, Surabaya: Arkola, h. 148.

${ }^{3}$ Priyambodo, Y., \& Gunarto, G. (2017). Tinjauan Terhadap Pelanggaran Kode Etik Jabatan Notaris Di Kabupaten Purbalingga. Jurnal Akta, 4(3), h. 335.

4 Yuniati, S. (2017). Mekanisme Pemberian Sanksi Terhadap Notaris Yang Melakukan Pelanggaran Kode Etik Jabatan Notaris. Jurnal Akta, 4(4), h. 588.

${ }^{5}$ Sundah, P. (2014). Tinjauan Yuridis Terhadap Tidak Dilaksanakannya Kewajiban Jabatan Notaris Menurut Undang-Undang No. 2 Tahun 2014. Lex Et Societatis, 2(4), h. 36. 
pembuatan akta autentik dan tugas serta wewenang notaris lainnya selaku pejabat umum dapat berjalan sebagaimana mestinya. ${ }^{6}$

Pelanggaran - pelanggaran yang disebabkan oleh notaris memiliki sanksi - sanksi yang juga harus diterima oleh notaris yang melakukan pelanggaran tersebut. Bagi notaris yang melakukan tindak pidana, maka notaris tunduk pada Kitab Undang Undang Hukum Pidana (KUHP). UUJN hanya memberikan sanksi perdata atau ganti rugi, sanksi administrasi, dan tidak mengatur mengenai sanksi pidana. ${ }^{7}$ Notaris yang dalam prakteknya melakukan kesalahan berupa pelanggaran terhadap UUJN maupun Kode Etik Notaris akan dijatuhi sanksi yang diatur dalam UUJN dan Kode Etik Notaris. Sanksi terberat bagi notaris yang melakukan pelanggaran adalah pemberhentian dengan hormat maupun pemberhentian secara tidak hormat.

Salah satu permasalahan yang sering kali ditemukan dalam tugas dan wewenang notaris adalah permasalahan yang berkaitan dengan honorarium notaris. Honorarium notaris adalah pembayaran yang diberikan oleh penghadap yang menggunakan jasa hukum notaris dalam pembuatan akta otentik. Nominal pembayaran oleh penghadap kepada notaris berdasarkan pada permintaan dari masing - masing notaris sendiri yang jumlahnya telah diatur dalam UUJN dan Kode Etik Notaris. Pasal 36 ayat (1) UUJN menyatakan bahwa Notaris mempunyai suatu hak terhadap jasa hukum yang telah diperbuatnya yaitu berupa pembayaran honorarium yang diberikan oleh penghadap kepada notaris sesuai dengan kewenangan dari notaris tersebut, besarnya pembayaran atas jasa yang telah diberikan oleh notaris tersebut sesuai dengan nlai ekonomis dan nilai sosiologis dari akta autentik yang disusun oleh notaris. Kemudian dalam aturan yang telah diterapkan perkumpulan yaitu pada Pasal 4 angka 10 aturan perkumpulan yaitu Kode Etik Notaris disebutkan bahwa Notaris tidak diperbolehkan untuk menentukan jumlah honorarium yang harus dibayar oleh penghadap menjadi lebih rendah dari pada jumlah yang telah ditetapkan oleh perkumpulan. Pengaturan atas jasa honorarium notaris dalam UUJN hanya menyebutkan batas maksimal saja tanpa adanya batas minimal, kemudian Kode Etik Notaris mengatur bahwa besarnya jasa honorarium notaris sesuai dengan yang ditetapkan oleh perkumpulan Ikatan Notaris Indonesia (INI). Peraturan yang ada didalam UUJN dan Kode Etik Notaris dianggap tidak sinkron karena UUJN tidak mengatur batas minimum sedangkan Kode Etik INI mengatur batas minimum. Notaris memerlukan honorarium agar menjamin kepastian biaya hidup mereka, mulai dari keperluan pribadi hingga biaya operasional kantor notaris. Bagi notaris senior yang telah mempunyai banyak klien akan lebih mudah menetapkan tarif sesuai dengan yang ditetapkan perkumpulan, tetapi untuk notaris yang baru saja berpraktek akan sulit mendapatkan klien apabila ada batas minimum/patokan biaya honorarium tersebut. Berdasarkan penelitian yang dilakukan oleh Asri pudji astuti, notaris senior dan notaris yang baru dilantik mempunyai jumlah klien yang berbeda. Notaris senior bisa dengan bebas menetapkan tarif honorarium karena mereka telah mempunyai klien tetap, tetapi notaris baru sulit mendapatkan

\footnotetext{
${ }^{6}$ Purwaningsih, E. (2015). Bentuk Pelanggaran Hukum Notaris di Wilayah Provinsi Banten dan Penegakan Hukumnya. Mimbar Hukum-Fakultas Hukum Universitas Gadjah Mada, 27(1), h. 16

7 Setiabudhi, I. K. R., \& Swardhana, G. M. (2017). Sanksi Hukum Terhadap Notaris Yang Melanggar Kewajiban Dan Larangan Undang-Undang Jabatan Notaris. Acta Comitas, h. 112.
} 
klien sehingga penetapan tarif honorarium notaris sangat penting untuk ditetapkan. ${ }^{8}$ Bagaimana nasib notaris baru yang biaya honorariumnya sudah ditetapkan perkumpulan? Apakah notaris baru bisa benar - benar bersaing dalam mendapatkan klien?

Berdasarkan uraian tentang penetapan honorarium yang rendah di atas maka disusunlah jurnal yang berjudul Sinkronisasi Pengaturan Honorarium Jasa Notaris Antara UUJN Dengan Kode Etik Notaris. Berdasarkan latar belakang dan pemaparan mengenai honorarium jasa notaris diatas maka rumusan masalah yang diangkat yaitu: Bagaimanakah pengaturan tentang honorarium jasa notaris? Apakah sanksi bagi notaris yang tidak mematuhi aturan Kode Etik Notaris terkait aturan mengenai honorarium jasa notaris?

Penulisan jurnal ini memiliki dua tujuan yaitu tujuan yang bersifat umum dan tujuan yang bersifat khusus. Tujuan yang bersifat umum dari penelitian ini yaitu untuk mengembangkan bidang keilmuan yaitu ilmu hukum dalam bidang kenotariatan sebagai kajian hukum yang berhubungan dengan pengaturan terkait honorarium jasa notaris yang diatur dalam UUJN dan Kode Etik Notaris. Tujuan Khusus dari penulisan ini yaitu untuk mengetahui dan memahami pengaturan honorarium jasa notaris yang diatur dalam UUJN dan Kode Etik Notaris; serta untuk mengkaji dan menganalisis sanksi bagi notaris yang tidak mengikuti aturan Kode Etik Notaris terkait peraturan mengenai honorarium jasa notaris. Kajian teoritis yang berhubungan dengan penelitian yang dilakukan ini adalah diharapkan agar dapat bermanfaat bagi pembaca sehubungan dengan petunjuk untuk mendapatkan referensi khususnya dalam bidang kenotariatan dan memberikan tambahan sumber pemikiran mengenai Pengaturan terkait honorarium jasa notaris yang diatur dalam UUJN dan Kode Etik Notaris.

Manfaat penelitian ini secara khusus ditujukan kepada Notaris, akademisi, mahasiswa, serta masyarakat, dan untuk menambah pengetahuan bagi penulis. Kemudian bagi Notaris, penelitian ini dapat dijadikan bahan pemikiran terkait keseharian praktek notaris dalam pengaturan terkait honorarium jasa notaris yang diatur dalam UUJN dan Kode Etik Notaris; bagi tim Dosen dan Para Mahasiswa penelitian ini dapat berfungsi sebagai bahan pemikiran serta penunjang dalam kegiatan perkuliahan dalam hal sinkronisasi pengaturan honorarium jasa notaris yang diatur dalam UUJN dan Kode Etik Notaris. Penelitian ini juga diharapkan dapat menjadi petunjuk bagi warga masyarakat ketika mendapat masalah dalam hal Pengaturan terkait honorarium jasa notaris yang diatur dalam UUJN dan Kode Etik Notaris; bagi penulis, hasil penelitian ini agar dapat menjadi tambahan pengetahuan khususnya dalam hal Pengaturan terkait honorarium jasa notaris yang diatur dalam UUJN dan Kode Etik Notaris dan sebagai ketentuan akhir untuk menyelesaikan studi akhir di Magister Kenotariatan Fakultas Hukum Universitas Udayana.

\section{Metode Penelitian}

Metodologi yang digunakan dalam suatu penelitian hukum adalah menguraikan suatu prosedur untuk melakukan suatu penelitian hukum yang nantinya diharapkan akan

\footnotetext{
8 Astuti, A. (2016). Honorarium Notaris Sebagai Upaya Melindungi Hak Notaris Guna Kepastian Dan Keadilan (Studi di Kota Malang) (Doctoral dissertation, Universitas Brawijaya). h. 4 .
} 
mendapatkan hasil penelitian yang akurat dan dapat dipertanggungjawabkan. Penelitian hukum dilakukan dengan melakukan suatu proses dimana dilakukan pencarian aturan - aturan hukum, prinsip - prinsip hukum, serta doktrin - doktrin hukum yang hasil dari penelitian tersebut digunakan untuk menjawan isu hukum yang sedang diteliti. 9 Penelitian ini menggunakan penelitian hukum normatif. Penelitian ini berdasarkan pada konflik norma yaitu Pasal 36 ayat (2) UUJN yang mengatur tentang batas maksimum penetapan jasa pembayaran oleh Notaris. Pasal tersebut menyebutkan bahwa notaris tidak boleh meminta tarif pembayaran terhadap jasa notaris melebihi batas yang telah ditentukan oleh UUJN. UUJN tidak mengatur mengenai batas minimum tarif jasa pembayaran yang dilakukan oleh notaris tetapi batas minimum ditetapkan oleh perkumpulan Ikatan Notaris Indonesia. Hal ini menimbulkan konflik norma antara Pasal 36 UUJN dengan Pasal 4 angka 10 Kode Etik Notaris.

Penelitian tentang sinkronisasi peraturan antara UUJN dan Kode Etik ini menggunakan metode penelitian hukum normatif dengan studi kepustakaan yaitu melakukan penelitian terhadap aturan undang - undang yang ingin dikaji dan diteliti. Penelitian ini menggunakan pendekatan perundang - undangan (The Statute Approach). serta pendekatan konseptual (Conceptual Approach). Penelitian perundang-undangan dilakukan dengan melakukan penafsiran terhadap aturan undang - undang yang ada hubungannya dengan isu hukum yang diteliti. Penelitian ini menggunakan sumber bahan hukum primer yaitu berupa hasil penelitian berupa jurnal, buku, serta karya ilmiah lainnya yang bersumber pada keilmuan dibidang hukum sebagai referensi penelitian. Selain bahan hukum primer digunakan juga bahan hukum sekunder yakni kumpulan peraturan tertulis berupa produk negara yaitu peraturan Undang - Undang serta peraturan yang berasal dari organisasi. Bahan sekunder yang dimaksud diatas adalah Undang-undang Nomor 30 Tahun 2004 Tentang Jabatan Notaris, Undangundang Nomor 2 Tahun 2014 tentang Perubahan Atas Undang-undang Nomor 30 Tahun 2004 Tentang Jabatan Notaris, dan Kode Etik Notaris.

\section{Hasil dan Pembahasan}

\subsection{Pengaturan Tentang Honorarium Jasa Notaris.}

Notaris tidak menerima honorarium dari negara padahal negara yang mengangkat notaris sebagai pejabat umum tetapi notaris menerima upah/jasa atas akta autentik yang disusun dan disahkan oleh notaris dari para pihak yang telah menghadap kepada notaris tersebut atas perbuatan hukum yang dilakukan sesuai yang tertuang dalam Pasal 36 ayat (2) UUJN. ${ }^{10}$ Masyarakat menghadap kepada notaris sehingga kepentingan hukumnya menjadi terlindungi, hal ini diharapkan dapat menjadi jawaban atas kebutuhan masyarakat. ${ }^{11}$ Kewenangan notaris telah ditentukan oleh UUJN seperti yang telah tertuang dalam Pasal 15 UUJN, khususnya dalam pembuatan

\footnotetext{
${ }^{9}$ Marzuki, P.M (2005), Penelitian Hukum, Jakarta: Prenada Media, h. 35.

10 Sari, D. A. P. (2016). Makna Pemberian Jasa Hukum Secara Cuma-cuma Oleh Notaris Pada Orang Tidak Mampu Terkait Sanksi Yang Diberikan Oleh Undang-undang Jika Tidak Dipenuhi (Analisis Pasal 37 Ayat (1) Dan (2) Undang-undang Jabatan Notaris No. 2 Tahun 2014). Kumpulan Jurnal Mahasiswa Fakultas Hukum, h. 1-2.

${ }^{11}$ Mahmoud, A. R. (2014). Implikasi Hukum Bagi Notaris Yang Tidak Melekatkan Sidik Jari Penghadap Pada Minuta Akta. Kumpulan Jurnal Mahasiswa Fakultas Hukum, 1(1), h.3.
} 
akta yaitu perbuatan - perbuatan hukum yang diatur dalam undang - undang atau para pihak sendiri yang datang menghadap kepada notaris kemudian menyatakan keinginannya untuk dituangkan dalam bentuk akta notaris. 12 Berdasarkan kewenangan notaris tersebut maka ditentukanlah berapa honorarium untuk notaris yang telah membuat akta notaris. Honorarium adalah hak seorang notaris. Orang orang yang menghadap yang melakukan transaksi dihadapan notaris kemudian menuangkannya dalam akta autentik wajib membayarkan honorarium kepada notaris walaupun di sisi lain notaris wajib pula untuk memberikan bantuan secara suka rela tanpa meminta biaya kepada mereka yang tidak sanggup untuk membayar honorarium tersebut. ${ }^{13}$

Pasal 36 UUJN menerangkan bahwa seorang notaris memiliki hak untuk mendapatkan honorarium apabila telah menyelesaikan tugasnya membuat akta otentik dan hal - hal lainnya yang berhubungan dengan kewenangan notaris. Jumlah honorarium yang dapat diberikan kepada notaris berdasarkan atas nilai ekonomis dan nilai sosiologis dari setiap akta yang disusun serta disahkan oleh notaris tersebut. Nilai transaksi sampai dengan Rp. 100.000.000,00 (seratus juta rupiah) mendapatkan honorarium tidak lebih dari 2,5\% (dua koma lima persen) dari nilai/harga objek yang ada didalam akta. Nilai transaksi diatas Rp. 100.000.000,00 (seratus juta rupiah) sampai dengan Rp. 1.000.000.000,00 (satu milyar rupiah) mendapatkan honorarium tidak lebih dari 1,5\% (satu koma lima persen) nilai/harga objek yang ada didalam akta. Kemudian untuk transaksi diatas 1.000.000.000,00 (satu milyar rupiah) adalah berdasarkan dari kesepakatan antara para pihak dan notaris tetapi tidak lebih besar dari 1\% (satu persen) nilai/harga objek yang ada didalam akta.

Nilai sosiologis ditentukan berdasarkan pada fungsi sosial dari objek yang dituangkan dalam akta notaris yaitu tidak lebih dari Rp. 5.000.000.000,00 (lima juta rupiah). Pengaturan besar honorarium jasa notaris dalam UUJN adalah mengenai batas maksimal atau tidak melebihi yang telah ditetapkan oleh UUJN dan tidak ada batas minimumnya. Sedangkan Pasal 4 angka 10 Kode Etik Notaris menyebutkan bahwa besarnya honorarium jasa notaris dari setiap akta yang dibuat oleh notaris tidak lebih rendah dari yang telah ditetapkan oleh perkumpulan. Hal ini berarti Perkumpulan yaitu anggota Ikatan Notaris Indonesia (yang selanjutnya disebut INI) telah menetapkan batas minimum dari honorarium jasa notaris.

Pengaturan mengenai honorarium jasa notaris yang diatur dalam UUJN dan Kode Etik Notaris dianggap tidak sinkron sehingga memunculkan kebingungan di kalangan notaris dan masyarakat. Untuk menyelesaikan permasalahan yang berkaitan dengan hal tersebut maka diperlukan Teori Sinkronisasi. Berdasarkan Kamus Besar Bahasa Indonesia kata "sinkron" berarti sejalan, sejajar, sesuai, selaras. ${ }^{14}$ sedangkan kata "sinkronisasi" berarti perihal menyingkronkan, penyerentakan. ${ }^{15}$ jika diartikan

12 Adjie, H. (2015). Penafsiran Tematik Hukum Notaris Indonesia Berdasarkan Undang Undang Nomor 2 Tahun 2014 Tentang Perubahan Atas Undang - Undang Nomor 30 Tahun 2004 Tentang Jabatan Notaris, Bandung: PT Refika Aditama. h. 3.

13 Adjie, H. (2011). Hukum Notaris Indonesia (Tafsir tematik Terhadap UU No. 30 Tahun 2004 tentang Jabatan Notaris), Bandung: PT Refika Aditama. h. 108.

${ }^{14}$ https://kbbi.web.id/sinkron (diakses 30 November 2018)

${ }^{15} \mathrm{https://kbbi.web.id/sinkronisasi} \mathrm{(diakses} 30$ November 2018) 
berdasarkan pengertian diatas maka sinkronisasi dianggap sebagai upaya untuk mendapatkan suatu keselarasan. Sinkronisasi peraturan antara UUJN dan Kode Etik Notaris adalah upaya untuk menyelaraskan kedua peraturan tersebut agar tidak terjadi pertentangan antara peraturan perundang - undangan ada peraturan yang berasal dari profesi notaris. Untuk melakukan penelitian mengenai sinkronisasi peraturan perundang - undangan maka dapat dilakukan dengan cara vertikal dan horizontal. Penelitian secara vertikal dilakukan dengan menganalisa aturan undangundang yang memiliki derajat berbeda tetapi mengatur pada bidang yang sama. Penelitian secara horizontal dilakukan dengan menganalisa peraturan perundang undangan yang sama derajatnya dan mengatur pula bidang yang sama. ${ }^{16}$ Dalam susunan peraturan perundang - undangan terdapat 3 (tiga) asas preferensi. ${ }^{17}$ Asas asas preferensi terdiri dari Asas lex superior derogate legi inferiori yang menyatakan bahwa aturan undang - undang yang mengatur materi normatif yang sama tidak boleh ada pertentangan antara aturan yang lebih rendah dengan aturan undang - undang yang berada ditingkat lebih tinggi. Jika ada pertentangan atas norma tersebut maka aturan undang - undang yang lebih tinggi akan mengalahkan aturan undang - undang yang lebih rendah. Asas lex posteriori derogate legi priori yang menyatakan bahwa pertentangan antara undangan - undang yang mengatur materi normatif yang sama bisa terjadi yaitu antara peraturan perundang - undangan yang lama dengan peraturan perundang - undangan yang baru. Apabila aturan undang - undang yang baru tidak mencabut peraturan perundang - undangan yang lama dalam artian aturan yang lama masih berlaku tetapi peraturan tersebut saling bertolakbelakang maka aturan undang - undang yang lama akan dikalahkan oleh aturan undang - undang yang baru. Asas lex specialis derogate legi generali memiliki pengertian yaitu aturan undang - undang yang memiliki materi normatif yang sama bisa menjadi bertolak belakang antara aturan undang - undang yang bersifat umum dengan aturan undang - undang yang bersifat khusus. Apabila terjadi hal demikian maka aturan undang undang yang bersifat khusus akan mengalahkan aturan undang - undang yang bersifat umum. ${ }^{18}$

Berdasarkan ketidak sinkronan yang terjadi antara Pasal 36 UUJN dan Pasal 4 angka 10 Kode Etik Notaris maka dapat dilakukan sinkronisasi dengan cara penelitian secara vertikal yaitu menganalisa peraturan perundang - undangan yang derajatnya berbeda yang mengatur bidang yang sama. UUJN memiliki derajat yang lebih tinggi dari Kode Etik Notaris sehingga Kode Etik Notaris seharusnya dapat menyelaskan peraturan terkait honorarium jasa notaris terhadap UUJN. Selain itu untuk menentukan peraturan perundang - undangan manakah yang akan berlaku terkait pengaturan mengenai honorarium jasa notaris maka asas yang dapat digunakan adalah Asas lex superior derogate legi inferiori yang menyatakan bahwa aturan undang - undang yang mengatur materi normatif yang sama tidak boleh ada pertentangan antara aturan yang lebih rendah dengan aturan undang - undang yang berada ditingkat lebih tinggi. Jika

16 Mamudji, S. (2009). Metode Penelitian dan Penulisan Hukum. Depok: Badan Penerbit Fakultas Hukum Universitas Indonesia. h. 11.

17 Sari, D. A. W., Murni, R. R., \& Udiana, I. M. (2018). Kewenangan Notaris Di Bidang Cyber Notary Berdasarkan Pasal 15 Ayat (3) Undang-Undang Nomor 2 Tahun 2014 Tentang Perubahan Atas Undang-Undang Nomor 30 Tahun 2004 Tentang Jabatan Notaris. Acta Comitas, h. 222.

${ }^{18}$ Damang., \& Nusa, A. (2017). Asas dan Dasar - Dasar Ilmu Hukum (Suatu Pengantar Praktis Menuju Pemahaman Ilmu Hukum Secara Kompherensif). Yogyakarta: Genta Publishing. h. 58. 
ada pertentangan atas norma tersebut maka aturan undang - undang yang lebih tinggi akan mengalahkan aturan undang - undang yang lebih rendah.

UUJN dianggap sebagai aturan undang - undan yang lebih tinggi sedangkan Kode Etik Notaris adalah peraturan yang lebih rendah. UUJN mengatur mengenai batas maksimal dari honorarium jasa notaris yang boleh diminta oleh notaris kepada klien tetapi UUJN tidak mengatur batas minimal dari tariff jasa notaris tersebut. Tarif minimal diatur dalam Kode etik notaris yang menyebutkan bahwa batas minimal honorarium jasa notaris yang diminta oleh notaris kepada klien adalah sebesar yang ditentukan oleh perkumpulan. Jika melihat dari Asas lex superior derogate legi inferiori maka peraturan yang berlaku adalah peraturan yang tertuang didalam UUJN yaitu mengenai batas maksimum atau batas paling besar. Hal ini dapat meringankan notaris yang baru berpraktek karena mereka belum mempunyai klien tetap. Bagi notaris baru akan sangat sulit mendapatkan klien apabila honorarium jasa notaris yang ditetapkan setara dengan notaris - notaris lama yang telah memiliki banyak klien dan juga rekanan - rekanan notaris tersebut. Pengaturan mengenai batas minimum honorarium jasa notaris tidaklah tepat apabila diterapkan kepada notaris yang baru saja berpraktek karena klien akan mengganggap bahwa dengan biaya yang sama lebih baik mereka menggunakan jasa notaris yang sudah lama berpraktek sehingga dianggap sudah berpengalaman ketimbang notaris yang baru berpraktek yang belum berpengalaman.

\subsection{Sanksi Bagi Notaris Yang Tidak Mematuhi Aturan Kode Etik Notaris Terkait Aturan Mengenai Honorarium Jasa Notaris.}

Sanksi - sanksi yang diperuntukan bagi notaris dibuat agar para notaris dapat melakukan pekerjaan dan tugasnya dengan benar serta jujur sehingga akta autentik yang merupakan produk notaris diharapkan memberikan perlindungan dan kepastian hukum kepada para pengahadap yang ada akta tersebut serta memiliki kepentingan terhadap akta autentik tersebut. ${ }^{19}$ Sanksi yang ada dalam UUJN yang berhubungan dengan akta hanya akan membuat akta terdegradasi menjadi akta dibawah tangan. Apabila hal ini terjadi maka para pihak penghadap yang ada didalam akta dapat menuntut notaris agar memberikan ganti kerugian serta bunga kepada notaris yang bersangkutan. Tuntutan ganti kerugian serta bunga ini merupakan akibat bagi notaris yang tidak bertanggung jawab atas tugasnya sehingga nilai pembuktian akta tersebut tidak lagi kuat layaknya akta autentik tetapi akta tersebut hanya memiliki kekuatan pembuktian layaknya akta dibawah tangan. Sanksi berupa ganti kerugian, biaya biaya, serta bunga dapat dikategorikan sebagai sanksi perdata. Bagi notaris yang tidak menjalankan kewajiban dan tidak sesuai dengan tugas dan jabatannya dalam pembuatan akta autentik yang dibuat dihadapan dan oleh notaris sesuai dengan UUJN maka notaris dikenakan sanksi administratif sesuai yg tertuang dalam UUJN. Sanksi yang dapat diberikan kepada notaris yang melanggar saksi administratif yaitu teguran secara lisan, teguran secara tertulis, pemberhentian yang hanya sementara waktu, pemberhentian secara terhormat, dan sanksi yang paling berat adalah pemberhentian secara tidak hormat. Pasal yang dimuat dalam UUJN tidak serta merta memberikan sanksi pada setiap pelanggaran. Ada beberapa pasal UUJN yang tidak memberikan sanksi bagi pelanggarnya salah satunya ada Pasal 36 UUJN tentang honorarium notaris. Pasal 6 Kode Etik Notaris mengatur tentang sanksi, sanksi bagi anggota

${ }^{19}$ Adjie, H. (2015) . Op.cit., h. 57. 
perkumpulan yang melanggar kode etik perkumpulan notaris. Sanksi tersebut antara lain sanksi berupa peringatan bagi pelanggar, teguran bagi pelanggar, pemberhentian tetapi hanya sementara dari keanggotaan Perkumpulan Notaris, pemberhentian secara hormat dari keanggotaan perkumpulan Notaris, dan pemberhentian secara tidak hormat dari keanggotaan perkumpulan Notaris. Penentuan sanksi tersebut dengan cara melihat kualitas serta kuantitas pelanggaran yang dilakukan anggota perkumpulan Notaris.

Melihat adanya pertentangan antara Pasal 36 UUJN dan Pasal 4 angka 10 Kode etik notaris mengenai pemberian honorarium jasa yang boleh dimintakan oleh notaris kepada klien maka timbul permasalahan apakah notaris yang tidak mematuhi Pasal 4 angka 10 Kode Etik Notaris dapat dikenakan sanksi? Kode Etik bagi Notaris adalah kumpulan aturan moral yang dibentuk dan diprakasai oleh perkumpulan Ikatan Notaris Indonesia yang diatur didalam aturan perundangan - undangan serta berlaku bagi notaris - notaris sebagai anggota perkumpulan dan semua orang yang memegang jabatan sebagai notaris. Penentuan pemberian sanksi bagi notaris yang melakukan pelanggaran terhadap kode etik ditentukan terlebih dahulu oleh Dewan Kehormatan Pusat Ikatan Notaris Indonesia dengan pemeriksaan lebih dulu oleh Dewan Kehormatan Daerah pada tingkat kabupaten/kota atau Dewan kehormatan Wilayah pada tingkat propinsi dan Dewan Kehormatan Pusat pada tingkat nasional. Pasal 36 UUJN tidak mengatur sanksi mengenai honorarium jasa notaris dan dalam Kode Etik Notaris tidak ditentukan sanksi bagi notaris yang melakukan pelanggaran terkait honorarium sehingga diperlukan pemeriksaan terlebih dahulu oleh Dewan Kehormatan. Pekerjaan notaris sebagai pembuatan akta otentik mempunyai nilai tersendiri bagi notaris tersebut untuk membuat akta secara cermat dan teliti. ${ }^{20}$ Notaris sepatutnya diperbolehkan untuk menentukan honorarium atas jasa yang telah diberikannya kepada penghadap. Hal ini dilakukan sesuai dengan kesepakatan notaris tersebut dan para pihak yang menghadap dengan notaris tergantung pada kesulitan dan kerumitan pembuatan akta yang dibuat tersebut. Hal lain yang diperhitungkan adalah tingkat kemampuan pembayaran para pihak penghadap tanpa harus adanya batas minimum penentuan honorarium jasa notaris dalam pembuatan akta.

\section{Kesimpulan}

Pengaturan mengenai honorarium jasa notaris dimuat di UUJN dan Kode Etik Notaris. UUJN mengatur mengenai batas maksimal dari penetapan honorarium jasa notaris yang boleh diminta oleh notaris kepada klien tetapi UUJN tidak mengatur batas minimal dari tarif jasa notaris tersebut. Tarif minimal penetapan honorarium jasa notaris diatur dalam Kode etik notaris yang menyebutkan bahwa batas minimal honorarium jasa notaris yang diminta oleh notaris kepada klien adalah sebesar yang ditentukan oleh perkumpulan. Jika melihat dari teori sinkronisasi vertikal maka Kode Etik Notaris seharusnya menyelaraskan peraturan terhadap UUJN dan melihat dari asas lex superior derogate legi inferiori maka peraturan yang berlaku adalah peraturan yang tertuang didalam UUJN sehingga notaris dapat mengikuti aturan yang ada dalam UUJN mengenai batas maksimal penetapan honorarium jasa notaris.

${ }^{20}$ Adjie, H. (2011). Op.cit., h. 109. 
Kode Etik Notaris tidak mengatur sanksi bagi notaris yang melakukan pelanggaran terkait honorarium. Notaris sepatutnya diperbolehkan untuk menentukan honorarium atas jasa yang telah diberikannya kepada penghadap dan tidak perlu diberikan sanksi apabila melanggar pengaturan terkait honorarium jasa notaris dalam Kode Etik Notaris.

Pengaturan honorarium jasa notaris yang ada didalam Kode Etik Notaris dan UUJN perlu disinkronisasikan. Kode Etik Notaris hendaknya memberlakukan batas maksimal penetapan honorarium jasa notaris seperti yang diatur dalam UUJN sehingga tidak menimbulkan kebingungan bagi notaris untuk menetapkan tarif jasa dan mempermudah khususnya bagi notaris baru untuk mendapatkan klien.

\section{Daftar Pustaka}

Buku

Adjie, H. (2015). Penafsiran Tematik Hukum Notaris Indonesia Berdasarkan Undang Undang Nomor 2 Tahun 2014 Tentang Perubahan Atas Undang Undang Nomor 30 Tahun 2004 Tentang Jabatan Notaris, Bandung: PT Refika Aditama.

Adjie, H. (2011). Hukum Notaris Indonesia (Tafsir tematik Terhadap UU No. 30 Tahun 2004 tentang Jabatan Notaris), Bandung: PT Refika Aditama.

Mamudji, S. (2009). Metode Penelitian dan Penulisan Hukum. Depok: Badan Penerbit

Fakultas Hukum Universitas Indonesia.

Marzuki, P.M (2005), Penelitian Hukum, Jakarta: Prenada Media.

Soerodjo, I, (2003), Kepastian Hukum Hak Atas Tanah di Indonesia, Surabaya: Arkola.

\section{Jurnal}

Astuti, A. (2016). Honorarium Notaris Sebagai Upaya Melindungi Hak Notaris Guna Kepastian Dan Keadilan (Studi di Kota Malang) (Doctoral dissertation, Universitas Brawijaya).

Prayojana, D. A., Murni, R. R., \& Dharmawan, N. K. S. (2018). Pelaksanaan Penyelesaian Pelanggaran Kode Etik Notaris Tentang Pemasangan Papan Nama Notaris Di Kota Denpasar. Acta Comitas, 213-218.

Priyambodo, Y., \& Gunarto, G. (2017). Tinjauan Terhadap Pelanggaran Kode Etik Jabatan Notaris Di Kabupaten Purbalingga. Jurnal Akta, 4(3), 331-338.

Yuniati, S. (2017). Mekanisme Pemberian Sanksi Terhadap Notaris Yang Melakukan Pelanggaran Kode Etik Jabatan Notaris. Jurnal Akta, 4(4), 585-590.

Sundah, P. (2014). Tinjauan Yuridis Terhadap Tidak Dilaksanakannya Kewajiban Jabatan Notaris Menurut Undang-Undang No. 2 Tahun 2014. Lex Et Societatis, 2(4).

Purwaningsih, E. (2015). Bentuk Pelanggaran Hukum Notaris di Wilayah Provinsi Banten dan Penegakan Hukumnya. Mimbar Hukum-Fakultas Hukum Universitas Gadjah Mada, 27(1), 14-28.

Setiabudhi, I. K. R., \& Swardhana, G. M. (2017). Sanksi Hukum Terhadap Notaris Yang Melanggar Kewajiban Dan Larangan Undang-Undang Jabatan Notaris. Acta Comitas, 110-121.

Sari, D. A. P. (2016). Makna Pemberian Jasa Hukum Secara Cuma-cuma Oleh Notaris Pada Orang Tidak Mampu Terkait Sanksi Yang Diberikan Oleh Undang-undang Jika Tidak Dipenuhi (Analisis Pasal 37 Ayat (1) Dan 
(2) Undang-undang Jabatan Notaris No. 2 Tahun 2014). Kumpulan Jurnal Mahasiswa Fakultas Hukum.

Mahmoud, A. R. (2014). Implikasi Hukum Bagi Notaris Yang Tidak Melekatkan Sidik Jari Penghadap Pada Minuta Akta. Kumpulan Jurnal Mahasiswa Fakultas Hukum, 1(1).

Sari, D. A. W., Murni, R. R., \& Udiana, I. M. (2018). Kewenangan Notaris Di Bidang Cyber Notary Berdasarkan Pasal 15 Ayat (3) Undang-Undang Nomor 2 Tahun 2014 Tentang Perubahan Atas Undang-Undang Nomor 30 Tahun 2004 Tentang Jabatan Notaris. Acta Comitas, 219-227.

Damang., \& Nusa, A. (2017). Asas dan Dasar - Dasar Ilmu Hukum (Suatu Pengantar Praktis Menuju Pemahaman Ilmu Hukum Secara Kompherensif). Yogyakarta: Genta Publishing.

\section{Website}

Kamus Besar Bahasa Indonesia https://kbbi.web.id/sinkron diakses pada tanggal 30 November 2018.

Kamus Besar Bahasa Indonesia https://kbbi.web.id/sinkronisasi diakses pada tanggal 30 November 2018 